\title{
HPLC Quantification of Hydroxycinnamic and Organic Acids of Canadian Goldenrod (Solidago canadensis L.)
}

\author{
Fidan Suleymanova ${ }^{1, *}$, Olga Nesterova ${ }^{1}$, Alexey Matyushin ${ }^{2}$
}

\section{Fidan Suleymanova ${ }^{1, *}$, Olga Nesterova', Alexey Matyushin²}

\section{'Department of Chemistry, Institute of Pharmacy, Sechenov First Moscow State Medical University, 119991 Moscow, RUSSIA. \\ 2Department of Analytical Toxicology, Pharmaceutical Chemistry and Pharmacognosy, Institute of Pharmacy, Sechenov First Moscow State Medical University, 119991 Moscow, RUSSIA. \\ Correspondence}

Miss. Fidan Suleymanova

Sechenov First Moscow State Medical University, 8, Trubetskaya st., Moscow, 119991, RUSSIA

Phone no : + 7 926-349-07-62

E-mail: suleymanovafidan5@gmail.com

History

- Submission Date: 13-10-2018;

- Review completed: 12-12-2018;

- Accepted Date: 03-01-2019

DOI : 10.5530/pj.2019.11.62

Article Available online

http://www.phcogj.com/v11/i2

\section{Copyright}

(C) 2019 Phcog.Net. This is an openaccess article distributed under the terms of the Creative Commons Attribution 4.0 International license.

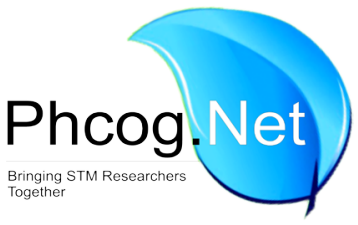

\begin{abstract}
Background: Canadian goldenrod (Solidago canadensis L.) is a medicinal plant widely used in traditional medicine across the world for several hundred years. According to literature data, S. canadensis contains various groups of biologically active substances, including tannins, flavonoids, etc. The aim of the study was to identify and quantify hydroxycinnamic and organic acids in aerial parts of Canadian goldenrod, as these groups of substances demonstrate a broad spectrum of therapeutic activities. Materials and Methods: Ethanolic extracts of S. canadensis, gathered in Central Russia, were analyzed using Highperformance liquid chromatography (HPLC). Hydroxycinnamic acids (HCA) determination was carried out by HPLC method with UV detection at $330 \mathrm{~nm}$ using HCA Reference standards (RS). Organic acids (OA) determination was performed in the same manner, utilizing UV detection at $210 \mathrm{~nm}$ and corresponding OA RS. Results: It was established that S. canadensis HCA composition is represented by cichoric, caffeic, chlorogenic, quinic and ferulic acids. The total HCA content in was $1.16 \mathrm{~g} \pm 10.7 \mathrm{mg} / 100 \mathrm{~g}$. Main $\mathrm{OA}$, found in S. canadensis, are ascorbic, citric, tartaric, succinic, gallic, malic, oxalic and fumaric acids, with the total OA content of $426.5 \mathrm{mg} \pm 6.4 \mathrm{mg} / 100 \mathrm{~g}$. Conclusion: The described HPLC method was successfully used for analysis of $S$. canadensis aerial parts ethanolic extracts. The method can be utilized for HCA and $\mathrm{OA}$ identification and quantification in both herbal raw material and herbal medicinal products containing Canadian goldenrod.

Key words: Hydroxycinnamic acids, Organic acids, Solidago canadensis, Canadian goldenrod, HPLC.
\end{abstract}

\section{INTRODUCTION}

Traditional medicine widely utilizes various herbal raw materials which are often used as a substitute of conventional drug products or as their supplement. Canadian goldenrod (Solidago canadensis L.) is well known in European traditional medicine for more than 700 years due to its pronounced anti-inflammatory properties. ${ }^{1}$ Goldenrod is also known to be used in ethnomedicine of people inhabiting Russia (Caucasus, Siberia), Moldavia and Belarus..$^{2-3}$ Currently, the importance of $S$. canadensis as a source of biologically active substances is officially recognized: corresponding monographs are included in the European and the British pharmacopoeias. ${ }^{4-5}$

Canadian goldenrod contains various groups of biologically active substances: flavonoids, tannins, saponins, essential oils. ${ }^{2-3}$ Many organic substances exhibit antioxidant activity, which is a natural factor of body protection. It is known that phenolic acids, tannins, flavonoids, quinones and organic acids ${ }^{1}$ display antioxidant activity. ${ }^{6-8}$

Hydroxycinnamic acids are the most common polyphenolic acids present in higher plants in the form of derivatives of glycosides or esters of cichoric, ferulic, coumarinic, caffeic acids with tartaric and quinic acids, as well as complexes with proteins, lignin and cellulose. In vitro tests of HCAs, namely chicoric, ${ }^{9}$ caffeic, quinic, ${ }^{10}$ ferulic $^{11}$ and chlorogenic, have confirmed their antioxidant and antiradical properties. $^{12}$ Moreover, ferulic acid demonstrates its therapeutic effects in a number of pathological conditions, including diabetes mellitus, cardiovascular and neurodegenerative disorders and even cancer. ${ }^{11}$ Organic acids include fumaric, malic, citric, tartaric, ascorbic, succinic, acetic, oxalic and others acids which show a wide spectrum of biological activity: anti-inflammatory, immunomodulating, and antioxidant activity. ${ }^{12,13}$

For example, succinic acid represents a good support for organism during hypoxia, as it plays an important role in citric acid cycle. A good antioxidant by itself, succinic acid effectively inhibits free-radical lipid peroxidation, activates superoxide dismutase, binds free radical and protects cellular membrane and apparatus. In addition, it also decreases histamine production, which, in turn, neutralizes inflammation and allergic reactions. It was found that succinic

Cite this article: Suleymanova F, Nesterova O, Matyushin A. HPLC Quantification of Hydroxycinnamic and Organic Acids of Canadian Goldenrod (Solidago canadensis L.). Pharmacog J. 2019;11(2):400-4. 
acid and its salts act as adaptogens that help organism to defend itself against negative effects of the environment. ${ }^{14}$

Ascorbic acid also involved in oxidation-reduction processes in living organisms and is an effective antioxidant. ${ }^{15}$

Oxalic acid is usually considered an inert product of metabolism; it was thought that only plant could metabolize oxalic acid. However, recent studies showed that oxalate level in animals are too high for it to be just an end product. It is suggested that there could be an oxalate oxidase pathway which utilizes oxalate to product hydrogen peroxide. Hydrogen peroxide, in turn, is used to stimulate oxidative burst. ${ }^{16}$

Literature data shows that citric acid demonstrates antibacterial properties against microorganisms present in dental plaque. ${ }^{17}$

Gallic acid and its salts, just as tartaric and citric acids, demonstrate antioxidant properties and is able form chelate complexes with metal ions. ${ }^{18-19}$ Together with citric acid, malic and fumaric acids are a part of tricarboxylic acid cycle which supplies cells with energy. ${ }^{20}$

Chlorogenic acid is an important biologically active dietary polyphenol that shows wide spectrum of biological activities: antibacterial, hepatoprotective, cardioprotective, antiinflammatory and antiviral. It was also found that this acid can modulate lipid and glucose exchange in metabolic disorders and, therefore, can possibly act as a therapeutic agent in cardiovascular diseases, diabetes mellitus, obesity and liver steatosis. ${ }^{21}$

Among therapeutic properties of cichoric acid, antiviral and anticancer activity should be mentioned. It was also suggested that cichoric acid and its analogues possess an anti-HIV activity due to its role in HIV integrase inhibition. ${ }^{22}$

Caffeic acid and quinic acid derivatives show demonstrate antioxidant properties. ${ }^{23-24}$

Some of the abovementioned properties may play pivotal role in the treatment of inflammatory periodontal diseases. Gum diseases not only may lead to tooth loss - they also can cause coronary heart disease and negatively affect adult population mortality rate,${ }^{25}$ so, periodontal disease remains an important public health problem. ${ }^{26}$ It is recognized that antioxidant activity expressed by different chemical substances is able to suppress periodontitis development. ${ }^{27}$ Therefore, herbal drug preparations containing Canadian goldenrod are important candidates for development of anti-inflammatory periodontal medicines.

Quantification of hydroxycinnamic and organic acids in raw plant material is one of the first steps in its standardization and development of novel herbal drug products that can be used to treat various diseases. Therefore, the aim of the study was to assess the content of HCA and OC in the dried aerial parts of $S$. canadensis.

\section{MATERIALS AND METHODS}

\section{Chemicals}

Reference standards (RS) of HCA ( $\geq 98.0 \%$, HPLC) (cichoric, caffeic, chlorogenic, quinic, chicoric and ferulic acids) and OA (ascorbic, citric, tartaric, succinic, gallic, malic, oxalic and fumaric acids) were purchased from Sigma-Aldrich Company Ltd (St. Louis, USA). High purity water was prepared using Millipore Milli-Q (Merck, Germany) water purification system. All other chemicals and reagents, such as potassium dihydrogen phosphate and phosphoric acid, were of analytical grade purity and were obtained from Merck (Darmstadt, Germany).

\section{Plant material collection}

The object of the study was whole aerial parts of the Canadian goldenrod

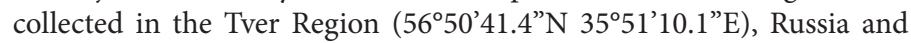
identified at the Department of Pharmaceutical Natural Science of the Institute of Pharmacy of Sechenov First Moscow State Medical
University (Sechenov University) and voucher specimen was stored at the department. Obtained material was air-dried under shade for 30 days.

\section{Determination of HCA}

HCA determination was carried out by HPLC method with UV detection at $330 \mathrm{~nm}$ using RS of HCA. HCA concentration was determined by means of external calibration (HCA standards by Sigma-Aldrich), using obtained peak areas. To prepare the HCA RS solutions with a concentration of $0.001 \mathrm{mg} / \mathrm{ml}, 25 \mathrm{mg}$ of substance was placed in a $50 \mathrm{ml}$ volumetric flask, dissolved in $25 \mathrm{ml}$ of $70 \%$ ethyl alcohol and brought to volume with ethanol. Gathered aerial parts of Canadian goldenrod (about $2.0 \mathrm{~g}$ ) were grounded in a mortar to a mushy state. Extraction was performed by $70 \%$ ethyl alcohol in a boiling water bath under reflux for $1 \mathrm{~h}$. Extracts analysis was performed using GILSON-305 liquid chromatography system (GILSON, France), which consisted of degasser, pump 5SC, thermostated autosampler (sample temperature $-15^{\circ} \mathrm{C}$ ), diode-array detector and thermostated chromatographic column $(250 \times 4.6 \mathrm{~mm}$, $5 \mu \mathrm{m}$, Kromasil $\left.\mathrm{C}_{18}\right)$. A phosphate buffer with $\mathrm{pH} 2.2$ was used as the mobile phase (27.2 $\mathrm{g}$ of potassium dihydrogen phosphate are placed in a 1-liter volumetric flask, dissolved in $500 \mathrm{ml}$ of purified water, brought to the volume with the same solvent and orthophosphoric acid is added to $\mathrm{pH}$ 2.2.). Chromatography parameters: flow rate $-1 \mathrm{~mL} / \mathrm{min}$, column temperature $-25^{\circ} \mathrm{C}$, injection volume $-20 \mu \mathrm{l}$. Chromatograms were processed using Multichrom software (Ampersend, Moscow, Multichrom Ltd, Russia).

\section{Determination of $\mathrm{OA}$}

OA determination was carried out by HPLC method with UV detection at $210 \mathrm{~nm}$ using RS of OA. OA concentration was defined with the aid of external calibration (OA standard by Sigma-Aldrich), based on peak areas. To prepare the OA RS solutions with a concentration of $0.001 \mathrm{mg} / \mathrm{ml}$, $25 \mathrm{mg}$ of substance were placed in a $50 \mathrm{ml}$ volumetric flask, dissolved in $25 \mathrm{ml}$ of $70 \%$ ethyl alcohol and brought to volume with ethanol. Gathered aerial parts of Canadian goldenrod (about $2.0 \mathrm{~g}$ ) were grounded in a mortar to a mushy state. Extraction was performed by $70 \%$ ethyl alcohol in a boiling water bath under reflux for $1 \mathrm{~h}$. Extracts analysis was performed using GILSON-305 liquid chromatography system (GILSON, France) which consisted of degasser, 5 SC pump, thermostated autosampler (samples temperature $-15^{\circ} \mathrm{C}$ ), diode-array detector and thermostated chromatographic column $(250 \times 4.6 \mathrm{~mm}, 5 \mu \mathrm{m}$, Kromasil C18). A phosphate buffer with $\mathrm{pH} 2.2$ was used as the mobile phase (prepared in the same manner as for determination of HCA.). Chromatography parameters: flow rate $-1 \mathrm{~mL} / \mathrm{min}$, column temperature $-25^{\circ} \mathrm{C}$, injection volume - $20 \mu \mathrm{l}$. Chromatograms were processed using Multichrom software (Ampersend, Moscow, Multichrom Ltd, Russia).

\section{RESULTS AND DISCUSSION}

\section{Hydrocinnamic acids}

The total HCA content in S. canadensis was found to be $1.16 \mathrm{~g} \pm 10.7$ $\mathrm{mg} / 100 \mathrm{~g}$. The HPLC-chromatogram of S. canadensis extract (cichoric, caffeic, chlorogenic, quinic and ferulic acids) is shown in Figure 1. The results of HCA determination are shown in Table 1.

\section{Organic acids}

The total OA content in S. canadensis was found to be $426.5 \pm 6.4 \mathrm{mg} / 100 \mathrm{~g}$. The HPLC-chromatogram of $S$. canadensis extract (ascorbic, citric, tartaric, succinic, gallic, malic, oxalic and fumaric acids) is shown in Figure 2. The results of OA determination are shown in Table 2. 


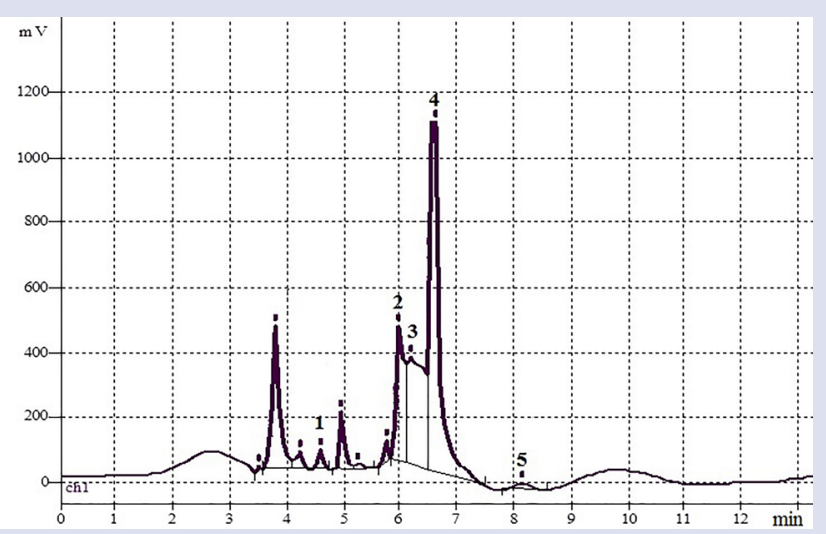

Figure 1: HPLC-UV chromatogram of S. canadensis: 1. Quinic acid; 2. Cichoric acid; 3. Chlorogenic acid; 4. Caffeic acid; 5. Ferulic acid.

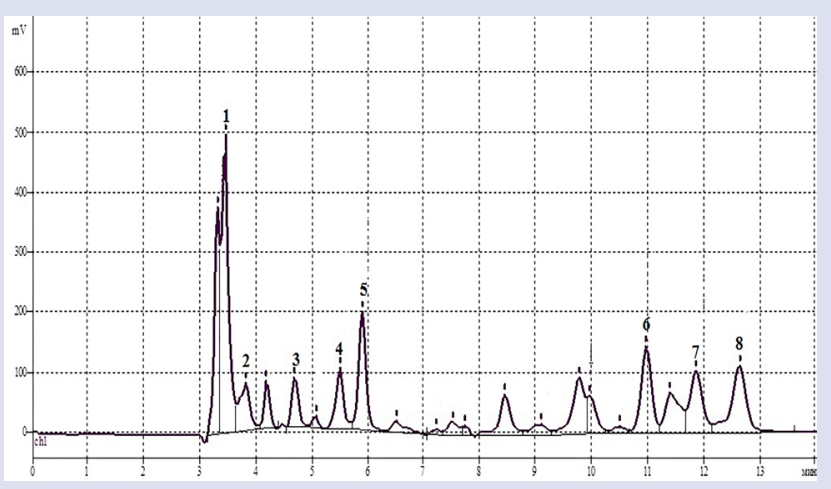

Figure 2: HPLC-UV chromatogram of S. canadensis: 1 . Oxalic acid; 2. Tartaric acid; 3. Malic acid; 4. Ascorbic acid; 5. Gallic acid; 6. Citric acid; 7. Fumaric acid; 8 . Succinic acid.

Table 1: Hydrocinnamic acids of Canadian goldenrod.

\begin{tabular}{|c|c|c|c|c|}
\hline HCA & $\begin{array}{l}\text { Retention } \\
\text { time, } t_{R}\end{array}$ & $\begin{array}{l}\text { Content, } \mathrm{mg} / 100 \mathrm{~g} \\
\text { of dry material }\end{array}$ & IUPAC name & Structure \\
\hline Cichoric & 5.948 & $240.0 \pm 6.3$ & $\begin{array}{c}\text { (2R,3R)-2,3-bis }\{[(E)-3 \text {-(3,4-dihydroxyphenyl)prop-2-enoyl }] \text { oxy }\} \\
\text { butanedioic acid }\end{array}$ & \\
\hline Chlorogenic & 6.175 & $320.2 \pm 5.4$ & $\begin{array}{c}\text { (1S,3R,4R,5R)-3-\{[(2E)-3-(3,4-dihydroxyphenyl)prop-2-enoyl }] \\
\text { oxy\}-1,4,5-trihydroxycyclohexanecarboxylic acid }\end{array}$ & \\
\hline Caffeic & 6.567 & $600.1 \pm 12.3$ & 3-(3,4-Dihydroxyphenyl)-2-propenoic acid & \\
\hline Quinic & 4.554 & $80.7 \pm 4.7$ & (1S,3R,4S,5R)-1,3,4,5-tetrahydroxycyclohexanecarboxylic acid & \\
\hline Ferulic & 8.113 & $4.3 \pm 0.7$ & (E)-3-(4-hydroxy-3-methoxyphenyl)prop-2-enoic acid & \\
\hline
\end{tabular}

Table 2: Organic acids of Canadian goldenrod.

\begin{tabular}{|c|c|c|c|c|}
\hline $\mathrm{OA}$ & $\begin{array}{c}\text { Time retention, } \\
t_{R}\end{array}$ & $\begin{array}{c}\text { Content, } \mathrm{mg} / 100 \mathrm{~g} \text { of } \\
\text { dry material }\end{array}$ & IUPAC name & Structure \\
\hline Ascorbic & 4.27 & $11.3 \pm 0.8$ & $\begin{array}{l}\text { (5R)-[(1S)-1,2-Dihydroxyethyl]-3,4-dihydroxyfuran- } \\
\text { 2(5H)-one }\end{array}$ & \\
\hline Citric & 8.05 & $11.1 \pm 0.8$ & 2-Hydroxypropane-1,2,3-tricarboxylic acid & \\
\hline Tartaric & 4.22 & $6.3 \pm 0.3$ & 2,3-Dihydroxybutanedioic acid & \\
\hline
\end{tabular}

Continued... 
Table 2: Cont'd.

\begin{tabular}{|c|c|c|c|c|}
\hline OA & $\begin{array}{c}\text { Time retention, } \\
t_{R}\end{array}$ & $\begin{array}{c}\text { Content, } \mathrm{mg} / 100 \mathrm{~g} \text { of } \\
\text { dry material }\end{array}$ & IUPAC name & Structure \\
\hline Succinic & 9.17 & $66.7 \pm 2.5$ & Butandioic acid & \\
\hline Gallic & 7.96 & $96.2 \pm 3.7$ & 3,4,5-Trihydroxybenzoic acid & \\
\hline Malic & 3.11 & $36.2 \pm 3.9$ & 2-Hydroxybutanedioic acid & \\
\hline Oxalic & 17.15 & $200.1 \pm 5.4$ & Oxalic acid & \\
\hline Fumaric & 6.89 & $5.0 \pm 1.1$ & (2E)-But-2-enedioic acid & \\
\hline
\end{tabular}

\section{CONCLUSION}

In this study, using the HPLC-UV method, organic and hydroxycinnamic acids contained in the aerial parts of $S$. canadensis were detected and quantified. The data obtained can be used to assess biological activity of Canadian goldenrod herbal raw material as well as the quality of herbal medicinal products containing this herb.

\section{ACKNOWLEDGMENT}

The study was supported by the "Russian Academic Excellence Project 5-100".

\section{CONFLICT OF INTEREST}

The authors declared no conflict of interest.

\section{ABBREVIATIONS}

HCA: Hydroxycinnamic acid; HPLC: High performance liquid chromatography; OA: Organic acid; RS: Reference standard; UV: Ultraviolet.

\section{REFERENCES}

1. Apáti P, Szentmihályi K, Kristó ST, Papp I, Vinkler P, Szoke E, et al. Herbal remedies of Solidago - correlation of phytochemical characteristics and antioxidative properties. Journal of Pharmaceutical and Biomedical Analysis. 2003;3(4-5):1045-53

2. Fedotova W, Chelombit'ko VA. Species of Solidago: value for the medical practice, the prospects of studying. Nauchnyi vedomosti BSU. Series: Medicine. Pharmacy. 2012;16(135):136-45

3. Sonova KV. Use of Solidago in modern medicine. Nauchnyj Medicinskij Vestnik. 2015;2(2):61-7.

4. European Pharmacopoeia 6.0 - Nordlingen. 2008.

5. British Pharmacopoeia. - London. 2009;1.

6. Pourmorad F, Hosseinimehr SJ, Shahabimajd N. Antioxidant activity, phenol and flavonoid contents of some selected Iranian medicinal plants. African Journal of Biotechnology. 2006;5(11):1142-5.

7. Yizhong C, Qiong L, Mei S, Harold C. Antioxidant activity and phenolic compounds of 112 traditional Chinese medicinal plants associated with anticancer. Life Sciences. 2004;74(17):2157-84.

8. Jaafar NS, Hamad MN, Abbas IS, Jaafar IS. Qualitative phytochemical comparsion between flavonoids and phenolic acids contents of leaves and fruits of Melia azedarach (Family: Meliaceae) cultivated in Iraq by HPLC and HPTLC. Int J Pharm Pharm Sci. 2016;8(10):242-50.
9. Line T, Johanna T, Alan M, Leif HS, Molgaard P. Antioxidant activity of cichoric acid and alkamides from Echinacea purpurea, alone and in combination. Food Chemistry. 2007;101(1):74-81.

10. Yuki S, Shirou I, Toshimitsu K, Jiro O, Masaki K, Takeshi $\mathrm{H}$, et al. In vitro and in vivo antioxidant properties of chlorogenic acid and caffeic acid. International Journal of Pharmaceutics. 2011;403(1-2):136-8.

11. Marimuthu S, Adluri RS, Venugopal PM. Ferulic Acid: Therapeutic Potential Through Its Antioxidant Property. Journal of Clinical Biochemistry and Nutrition. 2007;40(2):92-100.

12. Medvedev YV, Perederyaev OI, Arzamastsev AP, Eller KI, Prokofeva VI. Deter mination of hydroxycinnamic acids in raw medicinal plant materials and plant extracts. Questions of Biological, Medical and Pharmaceutical Chemistry. 2010;3:25-31.

13. Nollet LML, Toldrá F. Handbook of Food Analysis, Two Volume Set. CRC Press 2015.

14. Evglevskij AA, Ryzhkova GF, Evglevskaya EP, Vanina NV, Mikhajlova II, Denisova AV et al. Biologicheskaya rol' i metabolicheskaya aktivnost' yantarnoj kisloty. Vestnik Kurskoj Gosudarstvennoj Sel'skokhozyajstvennoj Akademii. 2013;9:67-9.

15. Eke PI, Dye BA, Wei L, Thorton-Evans GO, Genco RJ. Prevalence of periodontitis in adults in the United States: 2009 and 2010. Journal of Dental Research. 2012;91(10):914-20.

16. Mahmut Ç. The Metabolism of Oxalic Acid. Turk J Zool. 2000;24(1):103-6.

17. Daly CG. Anti-bacterial effect of citric acid treatment of periodontally diseased root surfaces in vitro. Journal of Clinical Periodontology. 1982;9(5):38-392.

18. Casimir CA, David BM. Food lipids Chemistry, Nutrition and Biotechnology. CRC Press. 2008.

19. Ermolaeva. Vliyanie syr'ya na kachestvo napitkov. Pivo I Napitki. 2005;1:54-5.

20. Israel G, Stefan RJ, Ophry P. Organic acids: old metabolites, new themes. Journal of Chemical Technology and Biotechnology. 2006;81(10):1601-11.

21. Naveed M, Hejazi $V$, Abbas M, Kamboh AA, Khan GJ, Shumzaid M, et al. Chlorogenic acid (CGA): A pharmacological review and call for further research. Biomed Pharmacother. 2018;97:67-74

22. Jungmin L, Carolyn FS. Chicoric acid: chemistry, distribution and production Front Chem. 2013:1:40.

23. Ilhami G. Antioxidant activity of caffeic acid (3,4-dihydroxycinnamic acid) Toxicology. 2006;217(2-3):213-20.

24. Tran MH, Min KN, Phuong TT, Nguyen DS, DaiEun S, Kyung SS, et al. Antioxidant activity of caffeoyl quinic acid derivatives from the roots of Dipsacus asper Wall. Journal of Ethnopharmacology. 2006;108(2):188-92.

25. Rekha C, Poornıma G, Manasa M, Abhıpsa V, Pavithra DJ, Vijay KHT, et al. Ascorbic acid, total phenol content and antioxidant activity of fresh juices of four ripe and unripe citrus fruits. Chem SciTrans. 2012;1(2):303-10.

26. FrankDe S, Robert FA, Henry SK, David FW, Carl MR. Dental disease and risk of coronary heart disease and mortality. BMJ. 1993;306(6879):688-91.

27. Brock GR, Butterworth CJ, Matthews JB, Chapple ILC. Local and systematic total antioxidant capacity in periodontitis and health. J Clin Periodontol. 2004;31(7):515-21. 
GRAPHICAL ABSTRACT

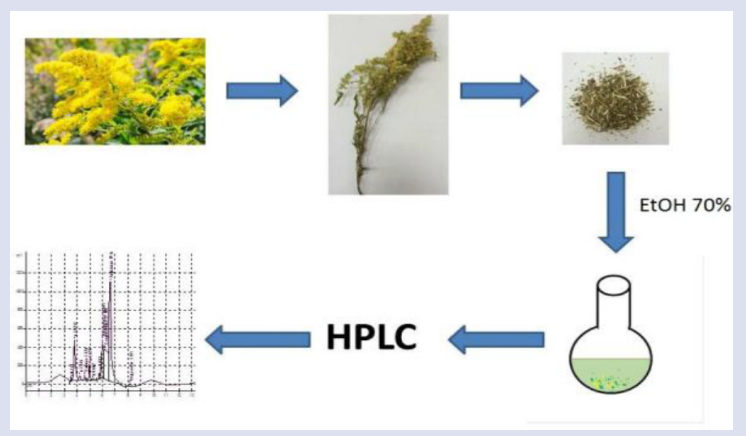

\section{SUMMARY}

- An HPLC method was used to assess hydroxycinnamic and organic acids content in Canadian goldenrod aerial parts.

- The total HCA and OA content was $1.16 \mathrm{~g} \pm 10.7 \mathrm{mg} / 100 \mathrm{~g}$ and $426.5 \pm 6.4$ $\mathrm{mg} / 100 \mathrm{~g}$, respectively.

- Among Canadian goldenrod OAs, oxalic acid was found to be most abundant $(200.1 \pm 5.4 \mathrm{mg} / 100 \mathrm{~g})$, the least abundant being fumaric acid $(5.0 \pm 1.1 \mathrm{mg}$ / $100 \mathrm{~g})$.

- Between HCAs, the caffeic acid content was found to be the highest $(600.1 \pm 12.3 \mathrm{mg} / 100 \mathrm{~g})$, whereas ferulic acid content was the lowest $(4.3 \pm$ $0.7 \mathrm{mg} / 100 \mathrm{~g})$.

Cite this article: Suleymanova F, Nesterova O, Matyushin A. HPLC Quantification of Hydroxycinnamic and Organic Acids of Canadian Goldenrod (Solidago canadensis L.). Pharmacog J. 2019;11(2):400-4. 